21 Briden, J. C., Nature, 215, 1334-1339 (1967).

22 Fyfe, W. S., and Leonardos, O. H., Nature, 244, 501-502 (1973).

${ }^{23}$ Spall, H., Nature, 236, 219-221 (1972).

24 Piper, J. D. A., Briden, J. C., and Lomax, K., Nature, 245, 244-248 (1973).

${ }^{25}$ Glikson A. Y., and Lambert, I. B., Earth planet. Sci. Lett., 20, 395-403 (1973).

${ }^{26}$ Fitch, T. J., Worthington, M. H., and Everingham, I. B., Earth plantet. Sci. Lett., 18, 345-356 (1973).

${ }^{27}$ Sykes, L. R., and Sbar, M. L., Nature, 245, 298-302 (1973),

2* Gordon, F. R., Royal Society of New Zealand, Bulletin 9, 85-93 (1971).

\section{Diamond growth by sulphide reduction of $\mathrm{CO}_{2}$}

MARX' proposed that natural diamonds were formed by a reduction of $\mathrm{CO}$ and other theories have been proposed to explain their formation"-i". Carbon dioxide is a common constituent ${ }^{7 . *}$ and has been found as a gas in natural diamonds". Marx proposed that pyrrhotite is active in the reduction process because it has been found as an inclusion in diamonds ${ }^{10}$. Furthermore, thermodynamic calculations showed such a reduction reaction to be energetically possible:

$$
2 \mathrm{FeS}(\text { solid })+\mathrm{CO}_{2} \text { (gas) }=2 \mathrm{FeO}(\text { solution })+\mathrm{S}_{2} \text { (gas) }
$$$$
+\mathrm{C} \text { (diamond) }
$$

Diamond formation by this reaction probably would result in inclusions containing either free sulphur or sulphur compounds, or both. To test this theory experimentally, natural diamond was oxidised by pure oxygen at a high temperature. Any included sulphur would be converted to gaseous $\mathrm{SO}$ and $\mathrm{SO}_{2}$ which could be detected by analysing the products with a research mass spectrometer. The instrument is about $10^{5}$ times more sensitive than any other spectroscopic method" and lends itself well to a study of minute quantities of a gaseous substance.

The mass spectrometer used was a $15.25-\mathrm{cm}$ radius $90^{\circ}$ sector type magnetic scanning instrument. The instrument, calibration and experimental procedures have been described".

Diamond fragments (16 g) were used". The diamond was placed in a quartz tube which was evacuated by an oil diffusion pump to $10^{-7}$ torr. An oxygen atmosphere of 1 torr was then admitted to the sample tube. The sample was heated to a temperature of $1,050^{\circ} \mathrm{C}$ and maintained at that temperature for $45 \mathrm{~min}$. The sample container was then placed in a dry ice-acetone bath and noncondensed components were removed by evacuation. Condensable substances were retained in the container. The remaining sample was analysed at room temperature using mass spectromatic techniques. Each experiment was duplicated three times. The weight of diamonds oxidised in each experiment was about $5.3 \mathrm{~g}$.

No evidence for $\mathrm{SO}$ and $\mathrm{SO}_{2}$ in the oxidation products was found in any of the three samples. The $16 \mathrm{~g}$ of oxidised diamond fragments comprised several hundred individual diamond crystals, some with visible inclusions, from Africa, Brazil and Arkanas. The detection sensitivity for sulphur was approximately 1 part in $10^{9}$ with respect to other oxidation products. Thus, there was no evidence for the presence of pyrrhotite. This suggests that the reduction of $\mathrm{CO}$, by pyrrhotite is not responsible for the formation of all natural diamonds. These limited data do not, however, rule out the possibility of some diamond formation by the reduction of $\mathrm{CO}$ : by pyrrhotite.
This study was supported by the National Science Foundation.

R. E. LANGFORD Charles E. Melton

Department of Chemistry,

A. A. Giardini

Department of Geology,

University of Georgia,

Athens, Georgia 30601

Received January 7; revised April 8, 1974.

1 Marx, P. C., Mineralog. Mag., 38, 636 (1972).

Meyer, H. O. A., and Boyd, F. R., Carnegie Inst. Wash. Geophys. Lab Report to Div. 1967-68 (1969).

"Lonsdale, K., and Milledge, H. J., in Physical Properties of Diamonds (edit. by Berman, R.), 42 (Clarenden Press, Oxford).

+ Dawson, J. B., Phil. Trans. R. Soc., A271, 297 (1972)

${ }^{5}$ Giardini, A. A., and Tydings, J. E., Am. Miner 47, 1393 (1962).

(5 Mitchell, R. H., and Crocket, J. H., Miner. Deposita, 6, 392 (1971).

Hearn, B. C., jun., Science, 159, 622 (1968).

"Kennedy, G. C., and Nordlie, B. E., Econ. Geol., 63, 495 (1968).

9 Melton, C. E., Solotti, C. A., and Giardini, A. A., Am. Miner., 57, 1518 (1972).

10 Sharp, W. E., Nature, 211, 402 (1966).

11 Melton, C. E., Principles of Mass Spectrometry and Negative lons (Dekker, New York, 1970).

12. Melton, J. phys. Chem., 74, 582 (1970).

\section{BIOLOGICAL SCIENCES}

\section{$E$. coli lactose operon ribosome binding site}

IN Escherichia coli, protein synthesis is initiated with formylmethionine, coded by the triplet AUG. As the first step in translation, ribosomes bind to the AUG initiator codon in the presence of initiation factors, charged fMet-tRNA and GTP. The sequence or structure of a messenger RNA molecule must signal that a particular AUG triplet is an initiation codon, and the cell's ribosomes must recognise this region as containing a signal for initiation of translation. In a reaction suitable for in vitro protein synthesis, except that it contains only one species of charged tRNA, fMet-tRNA, ribosomes bind to and protect initiation regions from nuclease digestion. The ribosomes bind at the AUG initiator codon and cannot proceed any further due to the lack of charged tRNA species other than fMet-tRNA. In the hope of determining the characteristics peculiar to an initiation region in a mRNA molecule, a number of ribosome binding sites have been sequenced ${ }^{1-8}$.

I have previously reported the sequence of the first 63 bases of the lactose operon mRNA transcribed from the (CAP-independent) UV5 promoter mutant ${ }^{9}$. Figure 1 shows this sequence. The first AUG triplet occurs at positions $39-41$, and the succeeding bases, read in triplets, code for the first seven amino acids of $\beta$-galactosidase ${ }^{10}$. This was highly suggestive that translation might initiate at position 39 of he UV5 lac message, and that ribosomes should bind to and protect the surrounding region of RNA from nuclease digestion.

To verify that the region around the AUG codon at position 39 is a ribosome binding site, I have isolated the portion of the UV5 lac mRNA which ribosomes protect from digestion by RNase $A$ (which cuts after $C$ and $U$ ) and RNase $T_{1}$ (which cuts after $G$ ). Table 1 lists the 